Provided for non-commercial research and education use. Not for reproduction, distribution or commercial use.

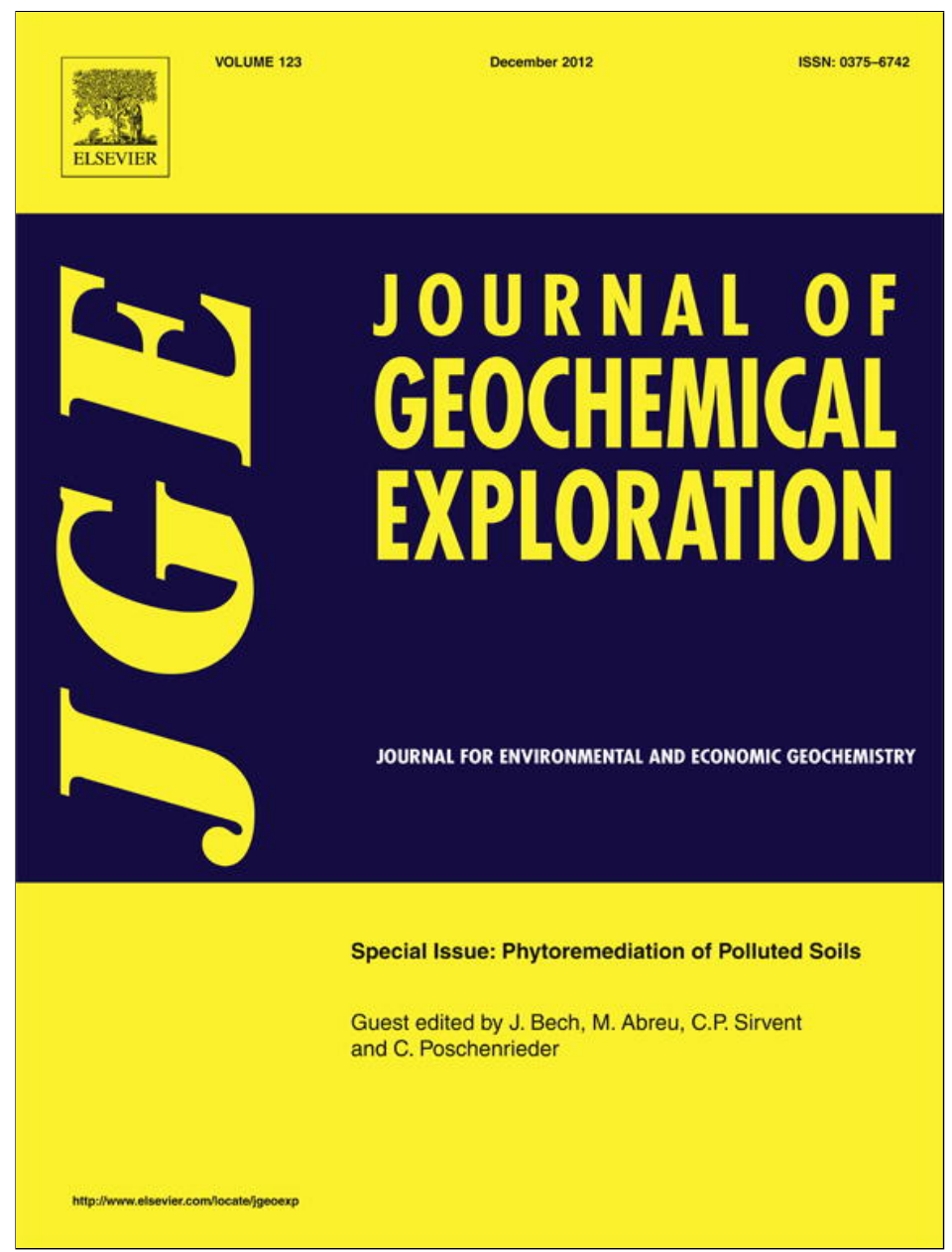

This article appeared in a journal published by Elsevier. The attached copy is furnished to the author for internal non-commercial research and education use, including for instruction at the authors institution and sharing with colleagues.

Other uses, including reproduction and distribution, or selling or licensing copies, or posting to personal, institutional or third party websites are prohibited.

In most cases authors are permitted to post their version of the article (e.g. in Word or Tex form) to their personal website or institutional repository. Authors requiring further information regarding Elsevier's archiving and manuscript policies are encouraged to visit:

http://www.elsevier.com/copyright 


\title{
Time and space variations in mercury and other trace element contents in olive tree leaves from the Almadén $\mathrm{Hg}$-mining district
}

\author{
P. Higueras ${ }^{\text {a,* }}$, J.A. Amorós ${ }^{\text {b }}$, J.M. Esbrí a ${ }^{\text {, F.J. García-Navarro }}{ }^{\text {b }}$, C. Pérez de los Reyes ${ }^{\text {b }}$, G. Moreno ${ }^{\text {b }}$ \\ a Instituto de Geología Aplicada-Laboratorio de Biogeoquímica de metales pesados, Universidad de Castilla-La Mancha, Pl. Manuel Meca 1, 13400 Almadén (Ciudad Real), Spain \\ ${ }^{\mathrm{b}}$ Instituto de Geología Aplicada, Escuela de Ingenieros Agrónomos de Ciudad Real, Universidad de Castilla-La Mancha, Ronda de Calatrava 7, 13071 Ciudad Real, Spain
}

\section{A R T I C L E I N F O}

Available online 9 May 2012

\section{Keywords:}

Mercury

Metallic trace elements

Olive tree leaves

Soils

Almadén

Spain

\begin{abstract}
A B S T R A C T
Olive trees (Olea europaea, L.) are a very important agricultural resource for Spain in general and for the Castilla-La Mancha region in particular. These trees provide significant amounts of olive oil and olives for direct consumption. In this paper we discuss analytical constraints regarding the uptake of metallic trace elements from soils and other sources for olive-trees growing in the Almadén mercury mining district, the world's largest producer of this element, which is currently inactive. The study was based on the analysis of these metals in soils and sets of olive trees of different ages from seven sites located at different distances from the main mercury sources. The results show good correlations between soil and leaf contents for major elements from the soils ( $\mathrm{Fe}, \mathrm{Al}, \mathrm{Mg}$ and $\mathrm{Ca}$ ), but very little or no relationship between metallic trace elements in soils and leaves. However, bioavailable mercury in the soil does correlate well with leaf contents, indicating a significant uptake of this fraction. Furthermore, detailed analysis of the temporal evolution of mercury contents in leaves compared with the temporal evolution of local atmospheric mercury contents, which decreased dramatically in recent years due to the reclamation of the main dump of the mine, indicates some influence of this parameter on the incorporation of mercury in the leaves and suggests a possible mechanism of atmospheric uptake of the element. Mercury contents in local olive oil and olives are slightly higher for samples taken from areas with also higher mercury concentrations in soils, but levels are well below maximum recommended levels for human food.
\end{abstract}

(c) 2012 Elsevier B.V. All rights reserved.

\section{Introduction}

\subsection{The study area}

The Almadén mercury mining district is located in the Castilla-La Mancha region in South-Central Spain (Fig. 1). This area corresponds to the biggest mercury geochemical anomaly in the world and has yielded almost one third of the total global production of this element (Hernández et al., 1999). Descriptions of the geological characteristics of the area can be found in reports by Saupé (1990) and Hernández et al. (1999), among others, while Lindberg et al. (1979), Huckabee et al. (1983), Higueras et al. (2003), Millán et al. (2004, 2006, 2011), Molina et al. (2006), Moreno-Jiménez et al. (2006), MartínezCoronado et al. (2011) have described environmental concerns regarding mercury in the area and include local soil/plant relationships. In particular, Molina et al. (2006) reported mercury contents in olive tree leaves, which is the main aspect discussed in this paper. Gray et al. (2004), Higueras et al. (2003, 2006) and Conde et al. (2008)

\footnotetext{
* Corresponding author.

E-mail address: pablo.higueras@uclm.es (P. Higueras).
}

describe high to very high mercury contents in soils at the regional scale; in particular, Conde et al. (2008) study a transect of mercury contents in soils from the Almadén periurban area and find mercury concentrations that point out to the element as a pollutant agent for drainage waters. Díez et al. (2011) studied mercury contents in the hair from inhabitants of the area and found slightly higher values for inhabitants of Almadén compared to those in surrounding areas, thus indicating a certain health risk.

From the physiographic point of view, the Almadén area is characterised by an Appalachian relief, meaning a landscape dominated by long 'sierras' and narrow valleys that follow approximately the E-W geologic structural trends; the 'sierras' correspond to quartzite outcrops and the valleys to shale-dominated geological formations (Fig. 1). As a semiarid area, with precipitation in the range $550-700 \mathrm{~mm} / \mathrm{year}$, dry farming agriculture and livestock dominate the activities in the valleys and the 'dehesa' (Spanish term for the regionally characteristic landscape of smooth plains and hills with tree vegetation dominated by oak trees, Querqus ilex), is the predominant landscape. Olive trees (Olea europaea, $L$.) are also quite common and these correspond to 'sierra' varieties and, in particular, to the 'Cornicabra' variety. Local soils have been classified as Cambisols (Leptic or Chromic) (Conde et al., 2008). 


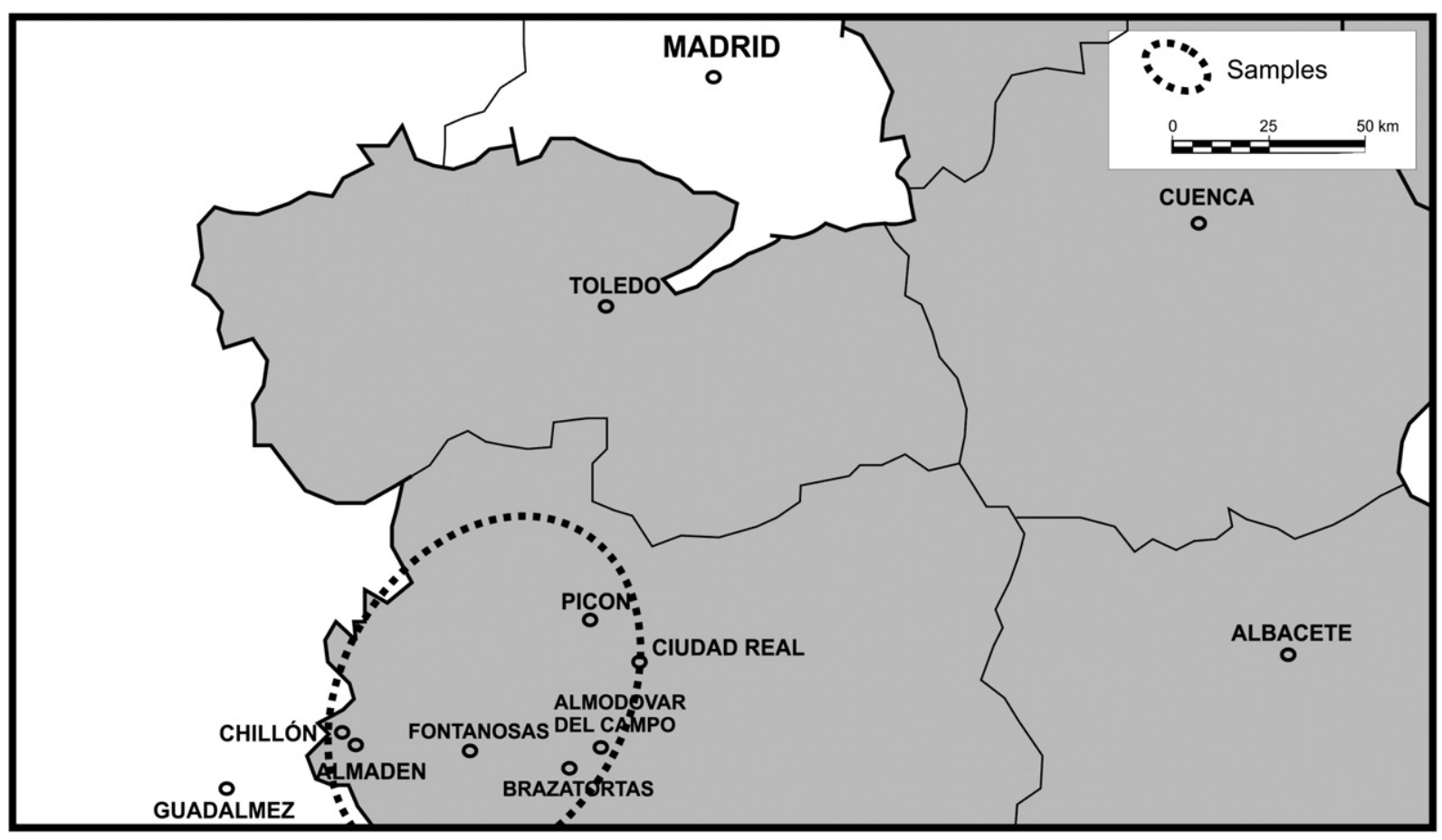

Fig. 1. Location of the study area. The Castilla-La Mancha region is shadowed. Locations mentioned in Table 1 are all shown in this scheme.

\subsection{Olive trees, soils and heavy metals}

The olive is a perennial leaf tree that has been cultivated for centuries. Nowadays, there are more than 8 million ha producing olives in the world and most of these are located around the Mediterranean Basin. In Spain there are more than 2 million ha with more than 300 million trees. Moreover, Castilla-La Mancha is the second largest region in Spain (below Andalucía) in terms of hectares dedicated to olive culture, with 300,000 ha approximately (Barranco et al., 2004).

It is well known that leaf analysis must be based on standardised sampling methods and that results must be compared only with standard values obtained by those procedures. Standard values for olives have been compiled by Fernández-Escobar et al. (1999) based on data reported by Bould (1966).

Several studies have been carried out in Mediterranean regions and areas of influence to investigate soil origins, parent materials and their characteristics (Amorós et al., 2010; Carlevalis et al., 1992). Indeed, recently published studies have focused on the area under consideration in this paper (Conde et al., 2009; De la Horra et al., 2008). The study of geochemical soil composition provides information, along with other complementary data, about fertility and the availability of nutrients for plants. Major elements provide information about total structural components and potential nutrients (Lanyon et al., 2004; White, 2009; Wild, 1992). On the other hand, contents of trace elements give an insight into the geochemical origin (García-Navarro et al., 2009) and potential toxicity (Conde et al., 2009; García-Navarro et al., 2009; Patra and Sharma, 2000) of the soil.

The metabolism of trace elements in plants has been widely studied (Kabata-Pendias, 2001; Wild, 1992). However, every plant-soil system has to be specifically studied, since the behaviour could differ depending on the elements present in a particular system (KabataPendias, 2001; Molina et al., 2006) as well as on the particular chemical form of the element in the soil. In all previously studied cases, plant composition (leaves, fruits, juices, tubers, etc.) always reflected the chemical properties of the cultivation environment (Bargagli, 1995; Kabata-Pendias, 2001; Vavoulidou et al., 2004; Zeiner et al., 2005).
It is widely accepted that 17 major and trace elements $(\mathrm{Al}, \mathrm{B}, \mathrm{Br}, \mathrm{Cl}$, $\mathrm{Co}, \mathrm{Cu}, \mathrm{F}, \mathrm{Fe}, \mathrm{I}, \mathrm{Mn}, \mathrm{Mo}, \mathrm{Ni}, \mathrm{Rb}, \mathrm{Si}, \mathrm{Ti}, \mathrm{V}$ and $\mathrm{Zn}$ ) are essential for plants; it has been proved that some of these are necessary only for certain species, whereas others only have stimulating effects for plant growth, but their functions have not yet been identified (Wild, 1992). Other elements seem to be not needed at all and are toxic to plants: $\mathrm{Hg}, \mathrm{Cu}, \mathrm{Ni}, \mathrm{Pb}, \mathrm{Co}$ and $\mathrm{Cd}$ and also possibly $\mathrm{Ag}$, Be and $\mathrm{Sn}$.

The olive tree is a pluriannual leaf tree and bears leaves from three different years. Some previous data on metallic element contents in these leaves have been reported (Bargagli, 1995; Gascó and Lobo, 2007; Madejón et al., 2006) and data for fertilisation programmes has been published (Bould, 1966; Fernández-Escobar et al., 1999; Vavoulidou et al., 2004). In general terms, the behaviour of these elements in leaves with time corresponds to three different models:

A. Accumulation with time. This behaviour corresponds to structural elements (Bould, 1966; Fernández-Escobar et al., 1999) and to elements that are difficult for the plant to excrete. This behaviour has been previously described for Ca (Bould, 1966; FernándezEscobar et al., 1999) and Ni (Madejón et al., 2006).

B. Decay in content with time. This model corresponds to essential elements that are necessary for the plant metabolism. Contents are therefore higher in young leaves and decay with time (Bould, 1966; Fernández-Escobar et al., 1999). Some potentially toxic elements such as $\mathrm{Pb}, \mathrm{Zn}$ and As show this behaviour (Madejón et al., 2006).

C. Constant elements. This behaviour corresponds to elements that have approximately constant concentrations in leaves. Mn and $\mathrm{Cu}$ correspond to this model (Madejón et al., 2006).

This work describes and discusses the distribution of mercury in olive tree leaves in the heavily contaminated area and surroundings outlined above, in order to assess the particular behaviour of this element in this plant, both in terms of time and space. Besides, we have analysed mercury contents in the edible fruits (olives) and in olive oil from the area, in order to eventually recognise risks for human consumption of these olive-tree derivate foods. Moreover, we compared 
$\mathrm{Ce}$

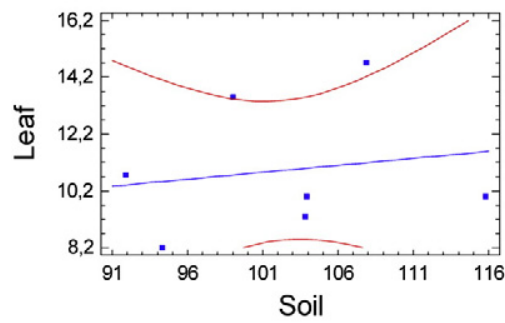

$\mathrm{Sr}$

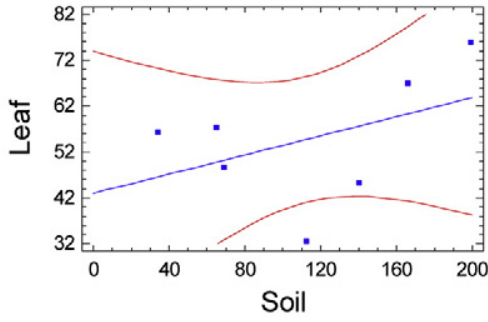

$\mathrm{Al}$

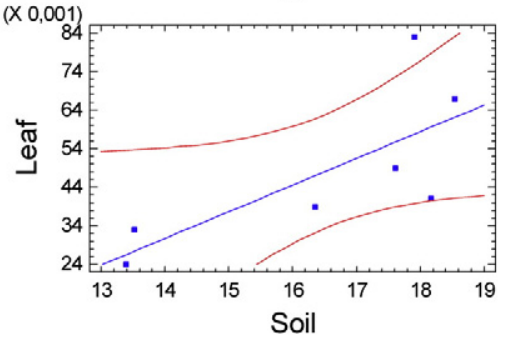

$\mathrm{Cr}$

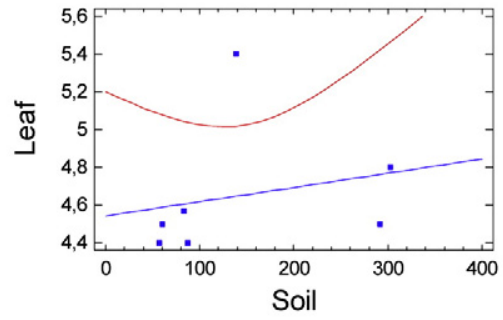

Cs

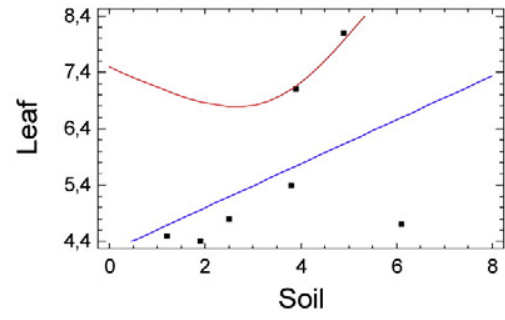

$\mathrm{Fe}$

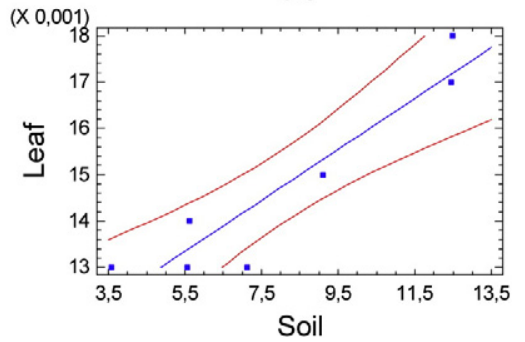

Fig. 2. Plot of linear correlations between soil and leaf contents for $\mathrm{Ce}, \mathrm{Cr}$ (low correlation observed), $\mathrm{Sr}, \mathrm{Cs}$ (positive correlation but not significant) and for Fe and Al (positive and significant correlation at 95\%). All data in $\mathrm{mg} \mathrm{kg}^{-1}$.

the Hg uptake with the uptake of other trace elements in order to better explain the absorption behaviour for this element in this plant.

\section{Materials and methods}

Sampling sites for this study were selected as a transect from the main mercury pollution sources and moved progressively away from them, up to a location situated some $74 \mathrm{~km}$ to the North of Almadén (see Table 1 for details). Sampling was carried out in one survey for soils and two surveys for leaves. The first survey was carried out in May 2010 and included soils and leaves. Soil samples were taken from the A Horizon, up to $10-50 \mathrm{~cm}$ depth, using peak and spade and a weight of $2.5 \mathrm{~kg}$ was removed in each case. The samples were stored and transported to the laboratory in plastic bags. Olive tree leaves were also taken during this survey and these were obtained from four different trees from each site, with leaves characterised as being from the present year, the previous year and the year before that as suggested by Barranco et al. (2004). In this way three sets of leaves were taken from each site with ages of 2 , 14 and 26 months, respectively.

The second survey was carried out in January 2011 and included only olive tree leaves, from the same sites sampled in the first survey; in this case leaves from that year had not grown yet, so two sets of leaves were collected from each of the seven sites (aged 8 and 20 months). Each set of leaves included at least 100 leaves. In

Table 1

Description of the sampling sites used for the present study. Distances to source correspond to distances to Almadén mine $(*)$ or to Almadenejos decommissioned metallurgical precinct $(* *)$.

\begin{tabular}{llcc}
\hline Site & Short description & X coord. & Y coord. \\
\hline 1 & Almadén urban area, south of the main dump & 340054 & Distance to source $(\mathrm{km})$ \\
2 & Almadén surroundings, close to a decommissioned metallurgical plant & 340075 & 4293486 \\
3 & Near Chillón, a locality 3 km NW from Almadén & 337813 & 4293871 \\
4 & Almadenejos, near an smelting facility with heavily Hg-contaminated soils & 351507 & 4294755 \\
5 & Fontanosas, supposed non-contaminated site & 366656 & 4289240 \\
6 & Almódovar del Campo, supposed non-contaminated site & 390909 & 4291811 \\
7 & Picón, supposed non-contaminated site & 407999 & $4.050\left({ }^{*}\right)$ \\
\hline
\end{tabular}


summary, five different sets of leaves were obtained, aged 2, 8, 14, 20 and 26 months, but these had different histories. Fruits (olives) were taken also from four different trees at sites 1,2 and 3 (Table 1) as well as from a blank area (Brazatortas) located some $50 \mathrm{~km}$ to the East of Almadén (Fig. 1). Olive oil was collected from two "almazaras" (the local name for the factories were the olive oil is extracted from olives), one located in Chillón (see Table 1 and Fig. 1) and processing olives from the whole Almadén area, and the second in Guadalmez, a village located some $13 \mathrm{~km}$ to the SW of Almadén (Fig. 1), and processing olives from an area with minor mercury presence in soils. Olive oil was of the "virgen extra" quality, so just extracted from olives by pressure, implying no chemical treatment at all.

Pre-treatment of soil samples included air-drying, homogenisation, sieving below $2 \mathrm{~mm}$, and taking an aliquot and grinding in an agate mortar to a grain size of $0.10-0.15 \mathrm{~mm}$; leaf samples were rinsed with deionised water, air-dried, ground and homogenised before chemical analysis.

Total mercury in soils was determined using a Lumex RA-915+ device, an Atomic Absorption Spectrometer with a pyrolysis unit (RP-91c) in which the sample matrix was destroyed and mercury atoms were counted by Atomic Absorption Spectroscopy with Zeeman effect to avoid any matrix effect on quantification (Molina et al., 2006; Sholupov et al., 2004). Bioavailable mercury was determined according to the methodology reported by Pérez et al. (2008). Briefly, this methodology involves lixiviate extraction with $0.5 \mathrm{M} \mathrm{HCl}$ for $1 \mathrm{~h}$ with magnetic stirring. The solid:water ratio was $1 \mathrm{~g}: 20 \mathrm{ml}$. After centrifugation at 3500 r.p.m. for $10 \mathrm{~min}$, the extracts were filtered through a $0.22 \mu \mathrm{m}$ filter (Millex-GS, Millipore) and analysed by AAS (AMA 254).

Total mercury in olive samples was determined using an Atomic Absorption Spectrometer (AMA254) fitted with a catalyser to dry and decompose the sample and then trap the mercury released in an amalgamator before quantification by Atomic Absorption Spectrophotometry. Quality control was achieved with equipment blanks, analysis of duplicates and certified reference material (SRM 2710). The detection limit for this matrix was $10 \mathrm{ng} \cdot \mathrm{g}^{-1}$, while precision and accuracy were $0.2 \%$ and $96.4 \%$, respectively. Determination of total mercury contents in olive oil and olives was carried out in the same way as for olive leaves, but using aluminium oxide to avoid explosions on the catalyser caused by combustible volatile compounds released during pyrolisation of these samples.

Multielemental analysis of solid samples was performed at the I.R.I.C.A. Laboratories (University of Castilla-La Mancha), by means of a sequential spectrometer Philips, mod. Magix Pro with a $4 \mathrm{~kW}$ light element super sharp RH target end window X-ray tube, a set of analyzer crystals of LiF220, LiF200, Ge, PE y PX1 and with a flow and a sealed proportional detector in tandem, plus a scintillation detector in parallel. The analysis of the samples was carried out as fused glass discs and using a specific calibration for soils and one adapted from fundamentals parameters for plants. Quality control was achieved with analysis of duplicate samples and certified reference material (NIST-2710a for soils and BCR-62 for plants), obtaining quantitative recoveries of $(87 \%-124 \%)$ in soil certified elements (Co, $\mathrm{Cu}, \mathrm{Zn}, \mathrm{As}, \mathrm{Sr}, \mathrm{Ba}, \mathrm{La}, \mathrm{Pb})$, and (76\%-153\%) in plant certified elements $(\mathrm{Cu}, \mathrm{Zn}, \mathrm{Pb})$. The rest of analysed elements are below detection limits or not certified at the corresponding reference materials, therefore their values may be considered as estimations.

Statistical data treatment was performed with STATGRAPHICS Plus 5.1 (Copyright@ 1994-2000 Statistical Graphics Corp.).

\section{Results and discussion}

\subsection{Metal contents in soils}

The analytical results for metal contents in the analysed soils are shown in Table 2 along with average and reference levels for Castilla-La

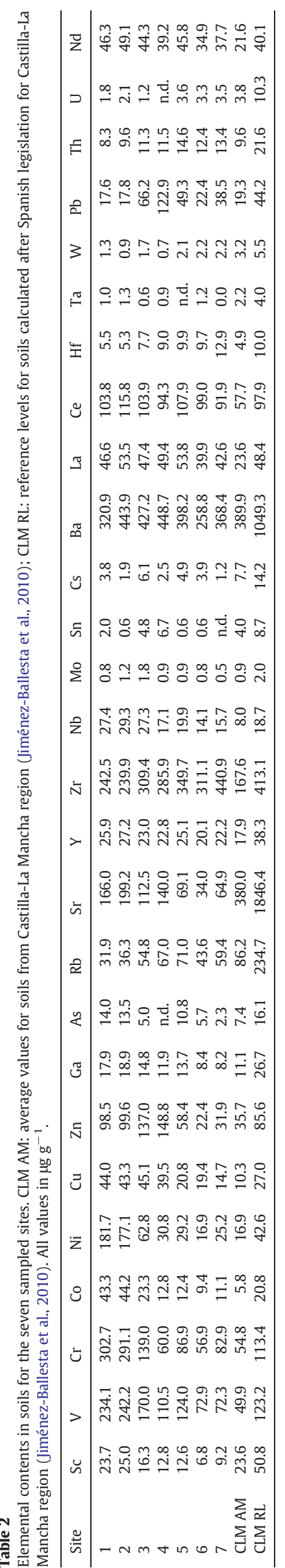


Mancha region (data from Jiménez-Ballesta et al., 2010). Most of the measured concentrations can be considered as normal contents for noncontaminated rural areas, with values close to or below those reported by Jiménez-Ballesta et al. (2010). On the other hand, some elements show concentrations well above these reference values; calcophilic elements such as $\mathrm{V}, \mathrm{Cr}, \mathrm{Co}, \mathrm{Ni}, \mathrm{Cu}, \mathrm{Zn}$ and $\mathrm{Pb}$ have concentrations above their Reference Levels for some of the analysed soils, particularly in proximity to urban areas: sites 1 and 2 are close to Almadén, site 3 is close to Chillón, and site 4 is close to Almadenejos. Besides, these sites are located in areas characterised by the presence of mafic magmatic rocks (GarcíaSansegundo et al., 1987), a situation that could explain these higher values-in particular for $\mathrm{V}, \mathrm{Cr}, \mathrm{Co}$ and $\mathrm{Ni}$. $\mathrm{Cu}$ and $\mathrm{Zn}$ are elements that are usually linked to periurban pollution (see Martínez-Coronado et al., 2011 for an example in Almadenejos). Pb shows maximum values in sites 3, 4 and 5, and this can be related to the regionally common galena (PbS) mineralisations exploited historically in the area. Similar soils have been studied in nearby areas by Amorós et al. $(2010,2011)$ and they often show a slightly acidic $\mathrm{pH}$ and relatively high clay content; these studies showed that many metallic elements are straightly linked to the clay fraction: $\mathrm{Fe}, \mathrm{Al}, \mathrm{V}, \mathrm{Cr}, \mathrm{Co}, \mathrm{Ni}, \mathrm{Cu}, \mathrm{Zn}$ and $\mathrm{Pb}$. García-Navarro et al. (2011) also stated that Rare Earth Elements are closely related to clay content in similar soils. It can be seen from Table 2 that relatively high contents were determined for $\mathrm{La}, \mathrm{Ce}$ and $\mathrm{Nd}$.

Furthermore, other elements, including $\mathrm{Rb}, \mathrm{Sr}$ and $\mathrm{U}$, show concentrations well below normal values for the region, a finding that can be explained in terms of regional geology variations. Sr is usually linked to carbonate rocks, which are very scarce in the Almadén area but are common in other geological domains in Castilla-La Mancha. $\mathrm{Rb}$ and $\mathrm{U}$ are usually linked to granites and gneisses, which are common in other areas of the region (Amorós et al., 2011; Conde et al., 2009) but not in the area under investigation. Mercury is, as expected (see Conde et al., 2008; Gray et al., 2004; Higueras et al., 2003, 2006), extremely high in the proximity of the mercury mining areas (Almadén and Almadenejos, sites 1,2 and 4 in Table 1) and contents clearly decrease with distance from these pollution sources. In particular, Conde et al. (2008) study a transect of mercury contents in soils from the Almadén periurban area and find mercury concentrations that point out to the element as a pollutant agent for drainage waters.

\subsection{Metal contents in leaves}

Average leaf contents for some major and trace elements are shown in Table 3 along with some reference values (Fernández-Escobar et al., 1999; Kabata-Pendias, 2001; Wild, 1992). Values in Table 3 correspond to averages of the values measured for the five leaf sets, with different ages, taken from each site; the complete measured concentrations can be found in Appendix 1 (Excel Table for additional material).

Measured values for $\mathrm{V}, \mathrm{Cr}$ and $\mathrm{Co}$ are above average world contents but are below toxicity levels. The $\mathrm{Pb}$ content is below world normal values but above contents reported for Calabria (Italy) by Bargagli (1995) $\left(<1 \mathrm{mg} \mathrm{kg}^{-1}\right)$. Ni values $\left(3.4 \mathrm{mg} \mathrm{kg}^{-1}\right)$ can also be considered as normal and below toxicity levels $\left(10 \mathrm{mg} \mathrm{kg}^{-1}\right)$ and this is consistent with data reported by Madejón et al. (2006) and Gascó and Lobo (2007); lower levels ( $\left.<1 \mathrm{mg} \mathrm{kg}^{-1}\right)$ were reported by Bargagli (1995) for Calabria (Italy). Zn levels $\left(21.1 \mathrm{mg} \mathrm{kg}^{-1}\right.$ ) are close to the world average and below values reported by Vavoulidou et al. (2004) for Greece $\left(68 \mathrm{mg} \mathrm{kg}^{-1}\right)$, and also below values measured by Madejón et al. (2006) in wild olive trees at Azcalcóllar (Seville, Spain) after the 1998 mining spill event $\left(60 \mathrm{mg} \mathrm{kg}^{-1}\right)$. Values for $\mathrm{Rb}, \mathrm{Sr}, \mathrm{Nb}, \mathrm{Cs}, \mathrm{La}, \mathrm{Ce}$ and $\mathrm{Nd}$ are reported here for the first time for olive tree leaves and references for these elements were not found in the literature.

The mercury content in leaves ranges from $0.2 \mathrm{mg} \mathrm{kg}^{-1}$ in the youngest leaves collected from the uncontaminated sites to $6.6 \mathrm{mg} \mathrm{kg}^{-1}$ for the oldest leaves from the area in proximity to the

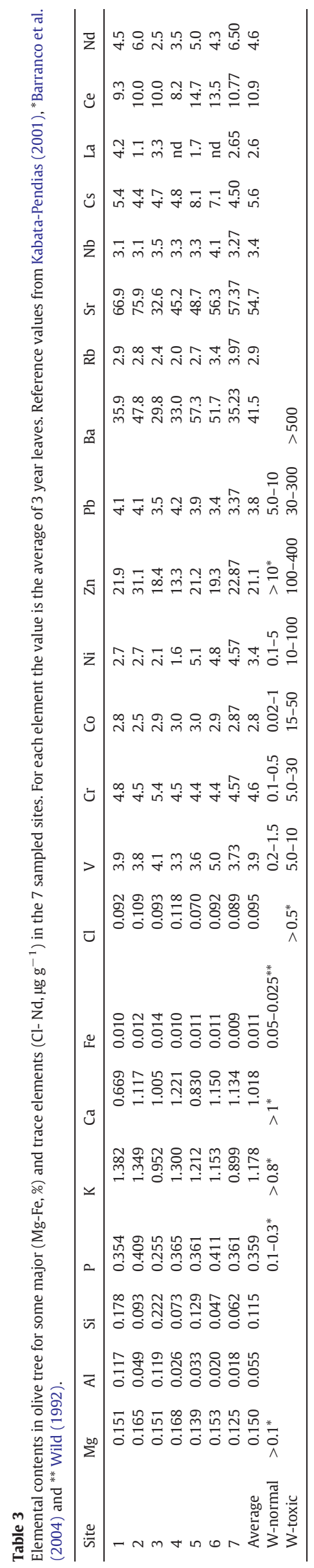


Almadén mine. Despite the fact that levels in some cases are above the $3 \mathrm{mg} \mathrm{kg}^{-1}$ value suggested as toxic by Kabata-Pendias (2001), visual symptoms of toxicity were not observed. Even with high concentrations of potentially toxic elements such as $\mathrm{Cr}, \mathrm{Ni}, \mathrm{Cu}, \mathrm{Zn}, \mathrm{Cd}$ and $\mathrm{Pb}$ coming from sewage sludge, toxic effects on olive trees can only be assessed to an excessive salt concentration (Gascó and Lobo, 2007).

\subsection{Soil-leaf relationships}

As stated previously, plant leaves contain variable quantities of trace elements depending on several factors: plant physiology, environmental conditions (mainly, elements available in the soil) and leaf age. Concerning our data for olive tree leaves from the Almadén mercury mining district, the $\mathrm{R}$ values and significance for simple linear correlation between soil and leaf contents for the seven studied sites are shown in Table 4 using average values for all leaf sets for each site. The data in Table 4 indicate that $\mathrm{Fe}, \mathrm{Mg}, \mathrm{Al}$ and $\mathrm{Ca}$ are the major elements that are clearly and positively related, indicating a direct and important uptake of these elements from the soil. In contrast, $\mathrm{K}$ and Si have significant but negative correlations. As far as trace elements are concerned (see Table 4 and Fig. 2), some element contents in leaves do not show any relationship with the element contents in the soil ( $\mathrm{Ce}, \mathrm{Cr}, \mathrm{Hg}, \mathrm{Nd}, \mathrm{Pb}, \mathrm{Zn}$ ), others show a positive relationship ( $\mathrm{Cs}, \mathrm{Sr}$ ) and the rest, such as $\mathrm{Ce}$ and $\mathrm{Cr}$, do not show a good soil/plant relationship, with $\mathrm{Ni}$ showing a negative correlation. These variations can be partially explained by the different bioavailability of the elements in these soils. For instance, in soils from Aznalcóllar (Seville, Spain) affected by the 1998 mine spill there is a large difference between total contents in the soils and available contents in wild olive trees: $\mathrm{Ni}$ falls from $27.5 \mathrm{mg} \mathrm{kg}^{-1}$ to $2.5 \mathrm{mg} \mathrm{kg}^{-1}$; Pb from $201 \mathrm{mg} \mathrm{kg}^{-1}$ to $43 \mathrm{mg} \mathrm{kg}^{-1}$ and $\mathrm{Zn}$ from $618 \mathrm{mg} \mathrm{kg}^{-1}$ to $174 \mathrm{mg} \mathrm{kg}^{-1}$ (Madejón et al., 2006). Better and more significant correlations $(\mathrm{R}=0.80$ for $\mathrm{Ca}, \mathrm{R}=0.84$ for $\mathrm{Mg}, \mathrm{R}=0.94$ for $\mathrm{Cr}$ and $\mathrm{R}=0.90$ for $\mathrm{Zn}$ ) have been obtained for olive trees (cv. Cornicabra) cultivated in pots and with controlled addition of sewage sludge (Gascó and Lobo, 2007). In natural soils, and considering old olive trees cultivated for a long time, these correlations are usually lower.

The soil/leaf relationship for mercury was of particular interest in this study. Mercury uptake from the soil depends to a large degree on the chemical species available in the soil, particularly in mining areas, where cinnabar is the main mercury form present in the soil (Llanos et al., 2011). As mentioned before, correlation between leaf contents and total mercury in the soil is very low $(R=0.131)$, but if we take into account the bioavailable mercury contents the correlation is high $(R=0.82)$, a finding that suggests the uptake of this element in these forms from the soil (Fig. 3).

The Biological Absorption Coefficient (BAC) is calculated as the ratio between the concentration of any studied element in the plant and the concentration found in the corresponding soil. An intermediate degree of accumulation has been suggested for $\mathrm{Hg}$, with a value close to 1 (Kabata-Pendias, 2001). For our data, and for the oldest leaves (aged 2 years), the mean BAC is 0.29 and this is lower than the general level for the world. However, one must take into account the high content in total $\mathrm{Hg}$ in the soils around Almadén.

\subsection{Temporal variations in leaf contents}

Our sampling methodology allowed us to study the temporal variations of trace elements in the study area in two different ways: variations in leaves grown in the same tree in different years could be analysed independently of the year considered, and variations could be studied related to the particular year in which the leaves grew and developed. The five leaf sets, with different absolute ages in months and corresponding to two different sampling years, were analysed.

Plots of the metallic trace element contents in leaves versus age in years of the leaves are shown in Fig. 4. Point 1 corresponds to the youngest leaves taken during the 2010 survey; point 2 to the average contents of the leaves with an age of 1 year taken in 2010 and 2011; and point 3 to the older leaves (aged 2 years) taken during the two surveys. Strontium represents behaviour-type A (accumulation with time); $\mathrm{Zn}, \mathrm{Cr}$ and $\mathrm{Rb}$ represents behaviour $\mathrm{B}$ (decay with time), a finding consistent with data from Fernández-Escobar et al. (1999) for Zn, and $\mathrm{Ni}$ conforms to type $\mathrm{C}$ behaviour (constant). Mercury also clearly corresponds to type A behaviour and accumulates in the olive tree leaves with time, particularly in the most heavily contaminated sites (1 and 2, located close to Almadén, and 4, located close to Almadenejos). On the other hand, a detailed analysis of this behaviour, considering the age of the leaves in months (Fig. 5), shows an anomaly: mercury contents in the 2 year old leaves taken during the 2011 survey have lower mercury contents than expected, in particular for sites 2 and 3, both of which are next to Almadén. In an effort to understand this anomaly, we must consider what happened during the period in which those leaves were growing. Mercury is a volatile element due its high vapour pressure, and so gaseous mercury pollution in mercury polluted areas is always an important factor (Gosar et al., 1997; Hagan et al., 2012; Kocman et al., 2011; Kotnik et al., 2005). Local atmospheric pollution has been described by Ferrara et al. (1998), Higueras et al. (2006) and Higueras et al. (2010), who reported concentrations between 1000 and $20,000 \mathrm{ng} \mathrm{m}^{-3}$ in the urban area and surroundings during the years prior to the corresponding publications. In particular, data from Ferrara et al. (1998) correspond to measurements carried out while cinnabar metallurgy was active, which can be considered as the main source of this pollution. Data from Higueras et al. (2006) correspond to two different surveys, carried out just before and just after cessation of the metallurgical activity, and these show a decrease in atmospheric mercury pollution after this cessation. Higueras et al. (2010) compared those data with new data obtained during and after the reclamation work carried out during 2007 and 2008 on the Almadén mine main dump, the principal source of atmospheric pollution after the metallurgy stopped. These data confirm the dump as the main source of gaseous mercury in the local atmosphere and indicate that after the reclamation process the gaseous mercury concentration fell to values well below $1000 \mathrm{ng} \mathrm{m}^{-3}$.

\subsection{Mercury contents in derived food}

Table 5 displays the mercury contents obtained from the local olives and olive oil compared with contents from the same sample type from uncontaminated areas. Results in the samples from the evidently contaminated areas are slightly higher than in the samples from

Table 4

Major and trace elements correlation ( $\mathrm{R}$ ) coefficient between soil-leaf content and their signification level.

\begin{tabular}{|c|c|c|c|c|c|c|c|c|c|c|c|c|c|c|c|}
\hline Element & $\mathrm{Al}$ & $\mathrm{Ca}$ & $\mathrm{Fe}$ & $\mathrm{K}$ & $\mathrm{Mg}$ & $\mathrm{Ce}$ & $\mathrm{Cr}$ & Cs & $\mathrm{Hg}$ & $\mathrm{Nd}$ & $\mathrm{Ni}$ & $\mathrm{Pb}$ & $\mathrm{Sr}$ & $\mathrm{Zn}$ & $\mathrm{Hg}$ \\
\hline $\mathrm{R}$ & 0.737 & 0.627 & 0.933 & -0.812 & 0.856 & 0.172 & 0.226 & 0.463 & 0.133 & 0.074 & -0.432 & 0.254 & 0.437 & -0.291 & 0.133 \\
\hline Signif. & $90 \%$ & $90 \%$ & $95 \%$ & $95 \%$ & $95 \%$ & No & No & No & No & No & No & No & No & No & No \\
\hline
\end{tabular}



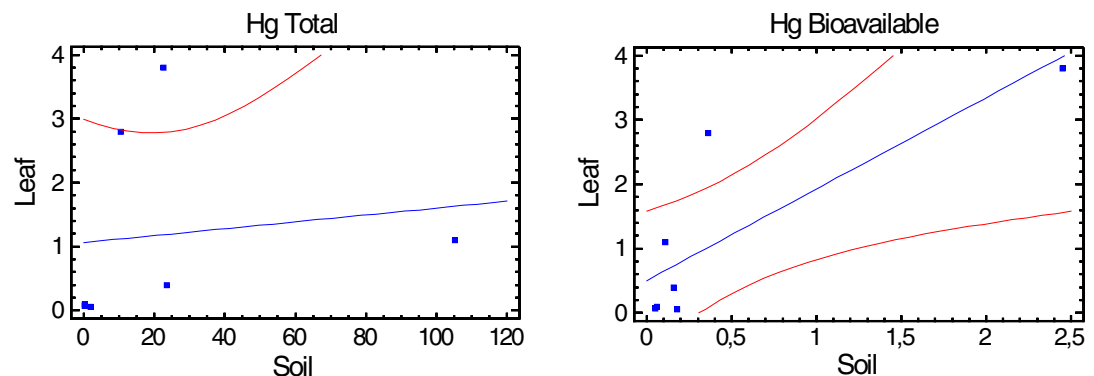

Fig. 3. Plot of linear dependence between total mercury in soil and mercury in leaves (left) and bioavailable mercury in soil and mercury in leaves (right). $\mathrm{R}=0.133$ (not significant) in the first case and $\mathrm{R}=0.82$ (significant at $95 \%$ ) for bioavailable mercury. All data in $\mathrm{mg} \mathrm{kg}^{-1}$.

uncontaminated areas; on the other hand, there is no European regulations concerning mercury contents in edible oil: Codex Alimentarius Commission (2003) states maximum contents of $0.1 \mathrm{mg} \mathrm{kg}^{-1}$ for As and $\mathrm{Pb}$ in olive oil, but makes no reference to mercury. Assuming a similar toxicity for these elements, the analysed olive oil from the Almadén area does not suppose a risk for local population, although it possibly contributes to the also slightly higher mercury concentrations in hair from the local inhabitants (Díez et al., 2011).
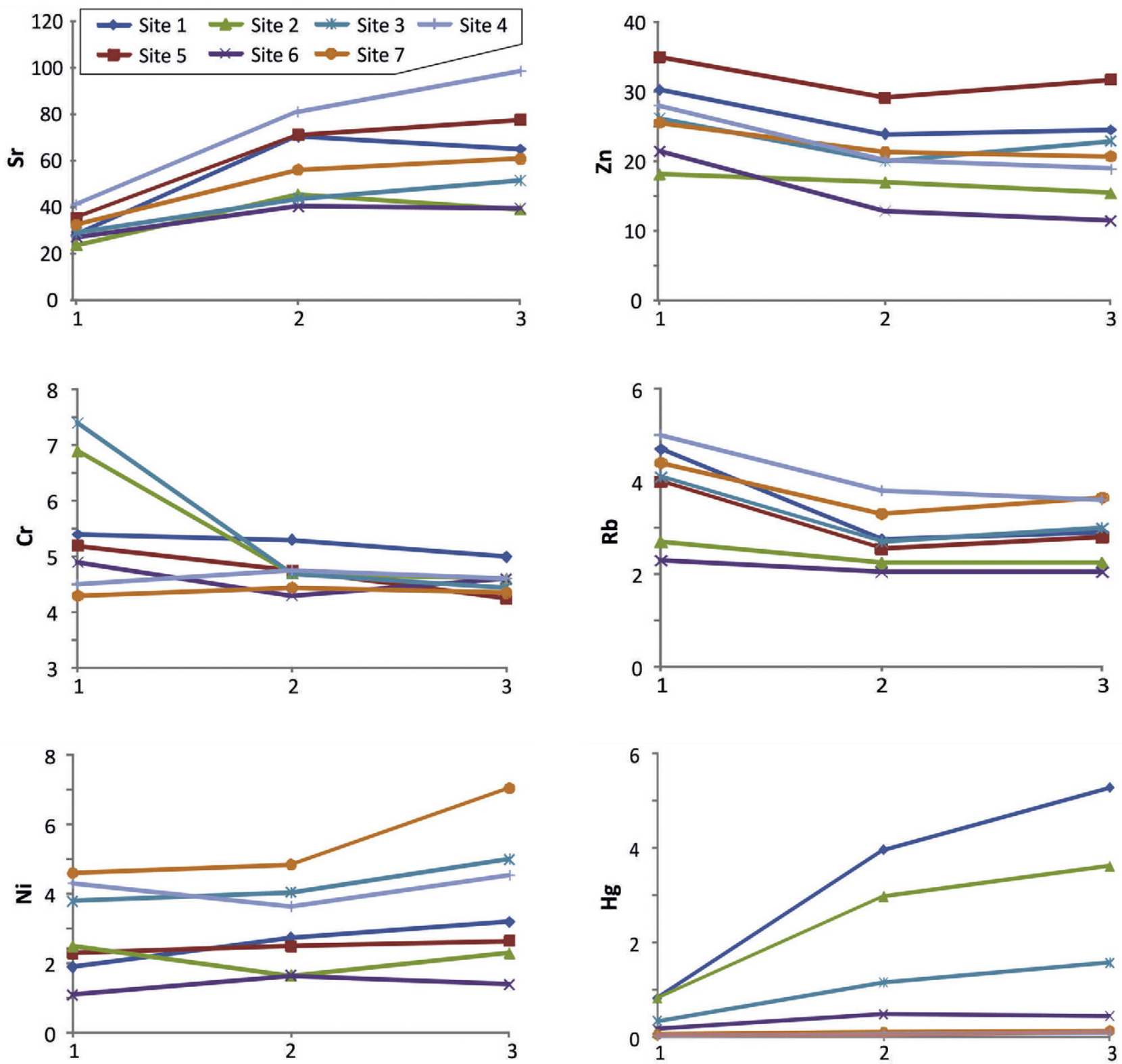

Fig. 4. Plot of trace metals contained in leaves versus their age in years. Point 1 corresponds to the youngest leaves taken during the 2010 survey; point 2 to the average contents of 1 year old leaves taken in 2010 and 2011; and point 3 to the older leaves (aged 2 years) taken during the two surveys. All concentrations in mg kg ${ }^{-1}$. 


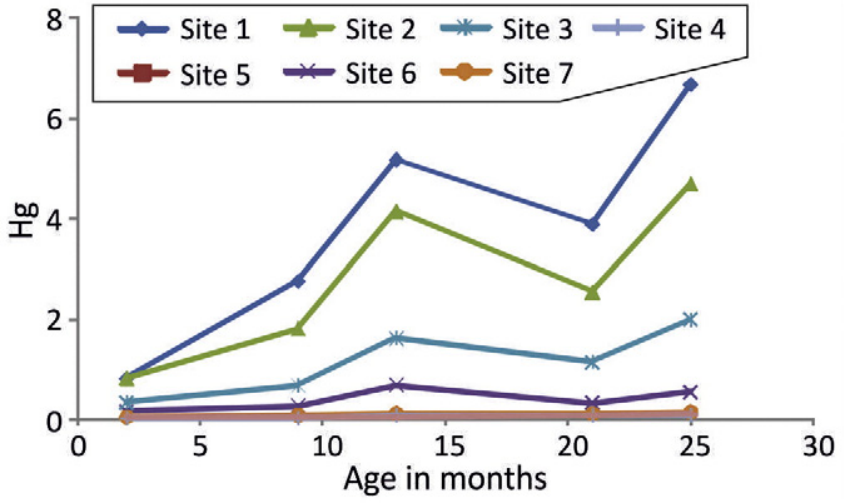

Fig. 5. Plot of mercury concentrations in leaves versus their age in months. Leaves aged 2, 14 and 25 months correspond to the first survey, carried out in May 2010, while leaves aged 8 and 21 months correspond to the second survey, carried out in January 2011. $\mathrm{Hg}$ concentrations in $\mathrm{mg} \mathrm{kg}^{-1}$.

\section{Conclusions}

The main conclusions of this study are outlined below:

1. Soils from the study area, centred in the Almadén mercury mining district, contain normal contents in metallic trace elements and these are conditioned by the local geology or urban locations of the area. Mercury is, as expected for this area, an exception to this trend, with very high concentrations that reach maximum values in the proximity of the known sources of the element: the proximity of mining and/or metallurgical areas in Almadén and Almadenejos.

2. Elemental concentrations in olive tree leaves are also normal, although our data are the first detailed data in this context for leaf samples. Apart from the major elements ( $\mathrm{Al}, \mathrm{Ca}, \mathrm{Fe}, \mathrm{K}, \mathrm{Mg}$ ), metallic contents in leaves do not show a relationship with soil contents, possibly due to the low bioavailability of these elements in the soils investigated. Mercury is also an exception and has high contents, well above published toxic levels, which do not correlate with total Hg contents in the soil but do show a strong correlation with bioavailable mercury.

3. The temporal evolution of metallic contents in the studied leaves showed that some elements became more concentrated with time ( $\mathrm{Sr}$ and $\mathrm{Hg}$ ), some elements decayed with time ( $\mathrm{Zn}, \mathrm{Cr}$ and $\mathrm{Rb}$ ) and some elements remained constant (Ni). Especially interesting was the study of the temporal evolution of mercury, which seems to have some correlation with changes in atmospheric mercury concentrations. The mercury concentrations reached maximum values in the leaves while those atmospheric concentrations were higher.

4. Based on the results of this study, the uptake of bioavailable mercury from the soils appears to be the main factor that explains the concentration of mercury in olive tree leaves. Furthermore, the temporal evolution of mercury contents in the leaves, with peaks during periods of higher atmospheric mercury concentrations, suggest aerial intake by leaves as an additional mechanism of mercury uptake.

Table 5

Mercury contents ( \pm standard deviation) in olive oil and olives from the Almadén area. See Table 1 for description of sites, and Fig. 1 for locations.

\begin{tabular}{ll}
\hline Sample type and location & $\mathrm{Hg} \mathrm{mg} \mathrm{kg}^{-1}$ \\
\hline Olives, site 1 & $0.162 \pm 0.010$ \\
Olives, site 2 & $0.077 \pm 0.007$ \\
Olives, site 3 & $0.018 \pm 0.002$ \\
Olives, Brazatortas & $0.045 \pm 0.007$ \\
Olive oil, Chillón & $0.049 \pm 0.011$ \\
Olive oil, Guadalmez & $0.011 \pm 0.001$ \\
\hline
\end{tabular}

Further studies involving a detailed investigation of this process are needed in order to confirm or modify this interpretation.

5. The usage as food of local olive oil and olives does not represent a risk for human health, although probably is a contribution for the higher levels of mercury in hair recognised for local population in previous studies.

\section{Acknowledgements}

The present study was funded by the Projects CGL2009-13171C03 (Ministerio de Ciencia e Innovación) and PII1109-0142-4389 (Viceconsejería de Universidades e Investigación, Consejería de Medio Ambiente, JCCM). The English language was reviewed by Neil Thompson (Scientific English).

\section{Appendix 1. Supplementary data}

Supplementary data to this article can be found online at http:// dx.doi.org/10.1016/j.gexplo.2012.04.012.

\section{References}

Amorós, J.A., Pérez de los Reyes, C. García-Navarro, FJ. Sánchez, C.J. Jiménez-Ballesta, R., 2010. Description of red soils in a semiarid climate and evaluation for vineyard (Vitis vinifera, L.) use. Fresenius Environmental Bulletin 19, 1199-1207.

Amorós, J.A., Pérez de los Reyes, C., García-Navarro, F.J., Sánchez, C.J., García, R. Jiménez-Ballesta, R., 2011. Trace elements distribution in red soils under semiarid Mediterranean environment. International Journal of Geosciences 2, 84-97. http:// dx.doi.org/10.4236/ijg.2011.22009.

Bargagli, R., 1995. The elemental composition of vegetation and the possible incidence of soil contamination of samples. Science of the Total Environment 176, 121-128.

Barranco, D., Fernández-Escobar, R., Rallo, L., 2004. El cultivo del olivo, fifth edition. Mundiprensa S.A., Madrid, Spain. 800 pp.

Bould, C., 1966. Leaf analysis of deciduous trees. In: Childers, N.F. (Ed.), Fruit Nutrition. Horticultural Publications, New Jersey, USA. 888 pp.

Carlevalis, J.J., De La Horra, J.L., Serrano, F., Rodriguez, J., 1992. La fertilidad de los principales suelos agrícolas de la zona oriental de la provincia de Ciudad Real. La Mancha y Campo de Montiel, vol. 1. C.S.I.C. and JCCM, Madrid. 294 pp. (ISBN: 84-00-07266-9).

Codex Alimentarius Commission, 2003. Draft revised standard for olive oil and olive pomace oils. Report of the eighteenth session of the Codex Committee on fats and oils. http://www.codexalimentarius.org/standards/list-of-standards/en/.

Conde, P., Bellido, E., Martín Rubí, J.A., Jiménez Ballesta, R., 2008. Concentration and spatial variability of mercury and other heavy metals in surface soil samples of periurban waste mine tailings along a transect in the Almadén mining district (Spain). Environmental Geology 56, 815-824.

Conde, P., Martín, J., De la Horra, J., Jiménez-Ballesta, R., 2009. Trace elements contents in different soils of a semiarid Mediterranean environment: Castilla-La Mancha, Spain. Fresenius Environmental Bulletin 18, 858-867.

De La Horra, J.L., Serrano, F., Carlevalis, J.J., 2008. Estudio de suelos del Campo de Calatrava (Ciudad Real) y sus condiciones de fertilidad, vol. 32. C.S.I.C., Madrid. 415 pp. (ISBN: 978-84-00-08625-1).

Díez, S., Esbrí, J.M., Tobias, A., Higueras, P., Martínez-Coronado, A., 2011. Determinants of exposure to mercury in hair from inhabitants of the largest mercury mine in the world. Chemosphere 84, 571-577.

Fernández-Escobar, R., Moreno, R., Garćia-Creus, M.,1999. Seasonal changes of mineral nutrients in olive leaves during the alternate-bearing cycle. Scientia Horticulturae 25-45.

Ferrara, R., Maserti, B.E., Andersson, M., Edner, H., Ragnarson, P., Svanberg, S., Hernandez, A., 1998. Atmospheric mercury concentrations and fluxes in the Almaden district (Spain). Atmospheric Environment 32, 3897-3904.

García-Navarro, F., Amorós, J.A., Sánchez, C.J., Bravo, S., Márquez, E., Jiménez-Ballesta, R., 2009. Application of sugar foam to red soils in a semiarid Mediterranean environment. Environmental Earth Sciences 59, 603-611.

García-Navarro, F., Amorós, J.A., Sánchez, C., Jiménez-Ballesta, R., 2011. Red soil geochemistry in a semiarid Mediterranean environment and its suitability for vineyards. Environmental Geochemistry and Health 33, 279-289.

García-Sansegundo, J., Lorenzo-Alvarez, S., Ortega, E., 1987. Mapa Geologico Nacional a escala 1:50 000, sheet 808 (Almadén), Instituto Geológico y Minero de España, Madrid, 64 pp.

Gascó, G., Lobo, M.C., 2007. Composition of a Spanish sewage sludge and effects on treated soil and olive trees. Waste Management 27, 1494-1500.

Gosar, M., Pirc, S., Sajn, R., Bidovec, M., Mashyanov, N.R., Sholupov, S., 1997. Distribution of mercury in the atmosphere over Idrija, Slovenia. Environmental Geochemistry and Health 19, 101-110.

Gray, J.E., Hines, M.E., Higueras, P.L., Adatto, I., Lasorsa, B.K., 2004. Mercury speciation and microbial transformations in mine wastes, stream sediments, and surface waters at the Almadén Mining District, Spain. Environmental Science and Technology $38,4285-4292$. 
Hagan, N., Robins, N., Hsu-Kim, H., Halabi, S., Morris, M., Woodall, G., Zhang, T., Bacon, A., Richter, D.B., Vandenberg, J., 2012. Estimating historical atmospheric mercury concentrations from silver mining and their legacies in present-day surface soil in Potosí, Bolivia. Atmospheric Environment 45, 7619-7626. http://dx.doi.org/ 10.1016/j.atmosenv.2010.10.009.

Hernández, A., Jébrak, M., Higueras, P., Oyarzun, R., Morata, D., Munhá, J., 1999. The Almadén mercury mining district, Spain. Mineralium Deposita 34, 539-548.

Higueras, P., Oyarzun, R., Biester, H., Lillo, J., Lorenzo, S., 2003. A first insight into mercury distribution and speciation in soils from the Almadén mining district, Spain. Journal of Geochemical Exploration 80, 95-104.

Higueras, P., Oyarzun, R., Lillo, J., Sánchez-Hernández, J.C., Molina, J.A., Esbrí, J.M., Lorenzo, S., 2006. The Almadén district (Spain): anatomy of one of the world's largest Hg-contaminated sites. Science of the Total Environment 356, 112-124.

Higueras, P., Esbrí, J.M., Oyarzun, R., Lorenzo, S., Llanos, W., Martínez-Coronado, A., López-Berdonces, M.A.. García Noguero, E.M., 2010. Mercurio en Almadén: desde su origen hasta su incorporación al medio ambiente. In: Loredo, J. (Ed.), Nuevos retos en la prospección e investigación de los recursos minerales - Libro Homenaje al Prof. Jesús García Iglesias. Departamento de Explotación y Prospección de Minas, Universidad de Oviedo, Oviedo, Spain, pp. 273-325.

Huckabee, J.W., Sanz Diaz, F., Janzen, S.A., Solomon, J., 1983. Distribution of mercury in vegetation at Almaden, Spain. Environmental Pollution Series A: Ecological and Biological 30, 211-224.

Jiménez-Ballesta, R., Conde-Bueno, P., Martín-Rubí, J.A., García-Jiménez, R., 2010. Pedogeochemical baseline contents levels and soil quality reference values of trace elements in soils from the Mediterranean (Castilla La Mancha, Spain). Central European Journal of Geosciences 2, 441-454.

Kabata-Pendias, A., 2001. Trace Elements in Soils and Plants, third ed. CRC Press, Boca Raton, USA. 413 pp.

Kocman, D., Vreča, P., Fajon, V., Horvat, M., 2011. Atmospheric distribution and deposition of mercury in the Idrija Hg mine region, Slovenia. Environmental Research $111,1-9$.

Kotnik, J., Horvat, M., Dizdarevic, T., 2005. Current and past mercury distribution in air over the Idrija $\mathrm{Hg}$ mine region, Slovenia. Atmospheric Environment 39, 7570-7579.

Lanyon, D., Cass, A., Hansen, D., 2004. The Effect of Soil Properties on Vine Performance CSIRO Land and Water Technical Report 34/04. Glen Osmond, Australia. 54 pp.

Lindberg, S.E., Jackson, D.R., Huckabee, J.W., 1979. Atmospheric emission and plant uptake of mercury from agricultural soils near the Almaden mercury mine. Journal of Environmental Quality 8, 572-578.

Llanos, W., Kocman, D., Higueras, P., Horvat, M., 2011. Mercury emissions and dispersion models from soils contaminated by cinnabar mining and metallurgy. Journal of Environmental Monitoring 13, 3460-3468. http://dx.doi.org/10.1039/C1EM10694E.

Madejón, P., Marañón, T., Murillo, J.M., 2006. Biomonitoring of trace elements in the leaves and fruits of wild olive and holm oak trees. Science of the Total Environment 355, 187-203.
Martínez-Coronado, A., Oyarzun, R., Esbrí, J.M., Llanos, W., Higueras, P., 2011. Sampling high to extremely high $\mathrm{Hg}$ concentrations at the Cerco de Almadenejos, Almadén mining district (Spain): the old metallurgical precinct (1794 to $1861 \mathrm{AD}$ ) and surrounding areas. Journal of Geochemical Exploration 109, 70-77.

Millán, R., Gamarra, R., Schmid, Th., Vera, R., Sierra, M.J., Quejido, A.J., Sánchez, D.M., Fernández, M., 2004. Mercury content in natural vegetation of three plots in the mining area of Almadén (Spain). RMZ-Materials and Geoenvironment 51, 155-158.

Millán, R., Gamarra, R., Schmid, T., Sierra, M.J., Quejido, A.J., Sánchez, D.M., Cardona, A.I., Fernández, M., Vera, R., 2006. Mercury content in vegetation and soils of the Almadén mining area (Spain). Science of the Total Environment 368, 79-87.

Millán, R., Schmid, T., Sierra, M.J., Carrasco-Gil, S., Villadóniga, M., Rico, C., Ledesma, D.M.S., Puente, F.J.D., 2011. Spatial variation of biological and pedological properties in an area affected by a metallurgical mercury plant: Almadenejos (Spain). Applied Geochemistry 26, 174-181.

Molina, J.A., Oyarzun, R., Esbrí, J.M., Higueras, P., 2006. Mercury accumulation in soils and plants in the Almadén mining district, Spain: one of the most contaminated sites on Earth. Environmental Geochemistry and Health 28, 487-498.

Moreno-Jiménez, E., Gamarra, R., Carpena-Ruiz, R.O., Millán, R., Peñalosa, J.M., Esteban, E., 2006. Mercury bioaccumulation and phytotoxicity in two wild plant species of Almadén area. Chemosphere 63, 1969-1973.

Patra, M., Sharma, A., 2000. Mercury toxicity in plants. The Botanical Review 66, 379-422.

Pérez, G., López-Mesas, M., Valiente, M., 2008. Assessment of heavy metals remobilization by fractionation: comparison of leaching tests applied to roadside sediments. Environmental Science and Technology 42, 2309-2315.

Saupé, F., 1990. Geology of the Almaden mercury deposit, province of Ciudad Real, Spain. Economic Geology 85, 482-510.

Sholupov, S., Pogarev, S., Ryzhov, V., Mashyanov, N., Stroganov, A., 2004. Zeeman atomic absorption spectrometer RA-915 + for direct determination of mercury in air and complex matrix samples. Fuel Processing Technology 85, 473-485.

Vavoulidou, E., Avramides, E.J., Papadopoulos, P., Dimirkou, A., 2004. Trace metals in different crop-cultivation systems in Greece. Water, Air, and Soil Pollution: Focus 4, 631-640.

White, R.E., 2009. Understanding Vineyard Soils. Oxford University Press. 230 pp.

Wild, A., 1992. Condiciones del Suelo y el Desarrollo de las Plantas según Russell. Ed. Mundiprensa, Madrid. $1045 \mathrm{pp}$.

Zeiner, M., Steffan, I., Juranovic, I., 2005. Determination of trace elements in olive oil by ICP-AES and ETA-AAS: a pilot study on the geographical characterization. Microchemical Journal 81, 171-176. 